\title{
A cost-utility analysis comparing omeprazole with ranitidine in the maintenance therapy of peptic esophageal stricture
}

Jeffrey M Stal MD FRCPC, James C Gregor MD FRCPC, Harold G Preiksaitis MD PhD FRCPC, Richard PE Reynolds MD FRCPC

JM Stal, JC Gregor, HG Preiksaitis, RPE Reynolds. A costutility analysis comparing omeprazole with ranitidine in the maintenance therapy of peptic esophageal stricture. Can J Gastroenterol 1998;12(1):43-49.

BACKGROUND: Recent studies have suggested that patients receiving omeprazole for prophylaxis against peptic esophageal stricture recurrence have less dysphagia and require fewer repeat dilations than patients receiving ranitidine.

OBJECTIVE: To estimate the incremental utility gain and associated incremental cost of omeprazole compared with those of ranitidine for the maintenance therapy of patients with peptic stricture who required esophageal dilation.

METHODS: Decision analysis using SMLTREE software was used to compare the incremental cost-utility of omeprazole $20 \mathrm{mg}$ once daily with that of ranitidine $150 \mathrm{mg}$ bid for one year. Variables were estimated from the literature, hospital data, and utility analyses involving patients with peptic stricture and health professionals. The primary outcome measure was cost per qualityadjusted life-years (QALYs) gained.

RESULTS: The incremental cost of omeprazole compared with that of ranitidine was $\$ 556$ per patient treated. The incremental utility gain of omeprazole was 0.0112 QALYs. Overall, the incremental cost:utility ratio of omeprazole in the maintenance therapy of patients with peptic stricture was $\$ 49,600$ per QALY gained. A sensitivity analysis revealed that the estimates with the greatest impact on the cost:utility ratio were disutility associated with dysphagia and dilation, the probability of requiring redilation and the cost of medications.
CONCLUSIONS: Omeprazole $20 \mathrm{mg}$ once daily is associated with greater utility and higher cost than ranitidine $150 \mathrm{mg}$ bid when used as prophylaxis against stricture recurrence. Omeprazole may be considered clinically and economically sufficient enough to warrant widespread use in this setting.

Key Words: Cost-utility analysis, Omeprazole, Peptic esophageal stricture, Ranitidine

\section{Analyse coût-qualité de vie comparant} l'oméprazole et la ranitidine dans le traitement d'entretien des strictures œesophagiennes d'origine peptique

DONNÉES DE DÉPART ET BUTS : Selon de récentes études, les patients qui reçoivent de l'oméprazole en prévention des récurrences de strictures œsophagiennes d'origine peptique souffrent moins de dysphagie et sont moins souvent candidats à la dilatation que les patients qui reçoivent de la ranitidine. L'objectif de cette étude était de mesurer, sur les plans de la qualité de vie et des coûts, les avantages de l'oméprazole par rapport à la ranitidine en traitement d'entretien chez les patients qui souffrent de strictures d'origine peptique et qui ont eu besoin de subir une dilatation œsophagienne.

MÉTHODES : L'analyse décisionnelle à l'aide du logiciel SMLTREE a été utilisée pour comparer le rapport coût-qualité de vie associé à l'oméprazole $20 \mathrm{mg}$ une fois par jour à celui de la ranitidine $150 \mathrm{mg}$ deux fois par jour

voir page suivante

Division of Gastroenterology, Department of Medicine, University of Western Ontario, London, Ontario

Correspondence: Dr James C Gregor, London Health Sciences Centre, Victoria Hospital Site, 375 South Street, PO Box 5375, London,

Ontario N6A 4G5. Telephone 519-667-6582, fax 519-667-6820, email jgregor@lhsc.on.ca

Received for publication June 16, 1997. Accepted October 20, 1997 
pendant un an. Les variables ont été calculées à partir de données tirées de la littérature, de dossiers hospitaliers et d'analyses de qualité de vie portant sur des patients souffrant de strictures d'origine peptique et de données recueillies auprès des professionnels de la santé. La principale mesure paramétrique a été le coût par QALY (quality-adjusted life-years ou années-personnes sans invalidité) gagnée.

RÉSULTATS : L'oméprazole a coûté 556 \$ de plus par patient traité comparativement à la ranitidine. L'avantage de l'oméprazole sur le plan de la qualité de vie a été de 0,0112 QALY. De façon globale, la différence du rapport coût-qualité de vie associé à l'oméprazole dans le traitement d'entretien des patients souffrant de strictures d'origine peptique a été de
49600 \$ de plus par QALY gagnée. Une analyse de sensibilité a révélé que les variables ayant produit le plus grand impact sur le rapport coût-qualité de vie ont été la désutilité associée à la dysphagie et la dilatation, ainsi que la probabilité de devoir recourir de nouveau à la dilatation et le coût des médicaments.

CONCLUSIONS : L'oméprazole, à raison de $20 \mathrm{mg}$ une fois par jour, est associé à une meilleure qualité de vie et à un coût plus élevé que la ranitidine $150 \mathrm{mg}$ deux fois par jour, lorsqu'il est utilisé en prévention des récurrences de strictures. L'oméprazole peut être jugé suffisamment attrayant sur les plans clinique et économique pour qu'on l'utilise davantage dans ce contexte.
$\mathrm{P}$ eptic esophageal stricture and dysphagia are serious complications of chronic gastroesophageal reflux disease. Among patients with reflux esophagitis seeking medical attention, the reported prevalence of peptic stricture varies considerably, ranging from $1 \%$ to $23 \%$ (1). The mainstay of treatment of peptic stricture is esophageal dilation, used most commonly with serial bougienage, which increases the diameter of the narrowed esophageal lumen. While dilation relieves the symptoms of dysphagia, it does not address the underlying pathological reflux, and, therefore, stricture recurrence requiring redilation remains a problem (2). Previous studies that examined the natural history of peptic strictures treated by dilation alone have revealed that nearly half of patients require redilation within one year $(2-4)$.

A logical therapeutic addition to dilation is acidsuppressive pharmacological therapy to control the underlying gastroesophageal reflux. However, previous trials with an $\mathrm{H}_{2}$-receptor antagonist $\left(\mathrm{H}_{2} \mathrm{RA}\right)$ as prophylaxis against stricture recurrence have had disappointing results $(5,6)$. Any potential benefit gained from the use of a more potent acidsuppressive medication, such as a proton pump inhibitor (PPI), has to be weighed against the substantial increase in cost.

In a recent study by Smith et al (7), patients with peptic stricture were randomized to receive maintenance therapy with either omeprazole $20 \mathrm{mg}$ once daily or ranitidine $150 \mathrm{mg}$ bid for one year after undergoing esophageal dilation. Significantly fewer patients who received omeprazole therapy complained of dysphagia or required redilation compared with those who received ranitidine. Marks et al (8) compared the cost effectiveness of omeprazole (20 mg once daily) with that of $\mathrm{H}_{2} \mathrm{RA}$ (ranitidine $150 \mathrm{mg}$ bid or famotidine $20 \mathrm{mg}$ bid) in the initial treatment of 34 patients with peptic stricture and coexistent erosive esophagitis. Six months after dilation, patients treated with omeprazole required fewer redilations than those treated with $\mathrm{H}_{2}$ RA. Omeprazole therapy was also more cost effective and was associated with a $40 \%$ reduction in overall costs to render a patient dysphagia-free.

A cost effectiveness analysis compares the incremental cost of an intervention with the incremental health effects of that intervention, and the results are expressed as cost per unit of effect. In contrast, a cost-utility analysis compares the incremental cost of an intervention with the incremental health improvement attributable to that intervention, and the health improvement is measured in quality-adjusted life-years (QALYs) gained; results are expressed as cost per QALY gained. By converting the effectiveness data to a common unit of measure, QALYs gained, a cost-utility analysis is able to consider simultaneously the increase in both quantity of life and quality of life (9). This allows an intervention to be compared not only with other treatments for peptic stricture, but also with any health-related treatment strategy.

In this study, a cost-utility analysis was used to compare alternative strategies in the management of patients with peptic esophageal stricture. The goal was to estimate the incremental utility gain and associated incremental cost of omeprazole compared with those of ranitidine for the maintenance therapy of patients with benign peptic stricture who required esophageal dilation.

\section{PATIENTS AND METHODS}

The decision analysis was applied to a specific subgroup of patients with benign peptic stricture who had been previously dilated to the point where they were dysphagia-free and had only been dilated as required for recurrent symptoms. In addition, these patients did not have other indications for maintenance therapy with a PPI, such as erosive esophagitis or symptomatic reflux refractory to $\mathrm{H}_{2}$ RAs.

Ten patients with recurrent peptic stricture who met the above criteria were interviewed to obtain utility scores for dysphagia and esophageal dilation. All patients were initially referred to the gastroenterology department at St Joseph's Health Centre, London, Ontario with a history of dysphagia. Patients' utility scores were included in the analysis if their esophageal stricture had required at least two previous esophageal dilations. To ensure accurate symptom recall, patients were included only if their most recent dilation was within one year of their utility assessment. Utility scores were also obtained from 20 health professionals working at St Joseph's Health Centre. These scores reflected their hypothetical disutility for esophageal perforation and for the requirement of having to undergo surgical and nonoperative treatment. All participants gave informed written consent under the principles of the second Declaration of Helsinki. 
Assessment of dysphagia: Dysphagia severity was determined by the patients' dysphagia score (Table 1). This score was the sum of the results from both the frequency scale (based on the frequency of dysphagia) and the diet scale (which assessed dysphagia associated with a variety of food types). Scores were obtained from patients' recall of their symptoms before and after their most recent dilation. The two scales used to generate the dysphagia score were modified from existing dysphagia indexes reported in the literature $(8,10,11)$.

Description of the decision model: Probabilities, outcomes and costs were based on a one-year time span extending from the patient's most recent dilation. All recurrent episodes of dysphagia requiring redilation and any treatment of potential complications of further dilations over that one year were taken into account. The probability and cost variables were estimated from the literature and hospital data. The decision analysis was performed using a decision tree (12) implemented with SMLTREE computer software (Jim Hollenberg, New York). The structure of the peptic stricture decision tree is summarized in Figure 1. Two alternative maintenance therapeutic options for patients with peptic stricture following esophageal dilation were evaluated: omeprazole $20 \mathrm{mg}$ once daily and ranitidine $150 \mathrm{mg}$ bid. In this model, patients
TABLE 1

Components of the dysphagia score for assessing severity of dysphagia

\begin{tabular}{lcc}
\hline Score & Frequency scale* & Diet scale $^{\dagger}$ \\
\hline 0 & None & None \\
1 & Less than once per week & Meat \\
2 & Weekly & Bread \\
3 & Daily & Apple \\
4 & Each meal & Banana \\
5 & Each swallow & Porridge \\
6 & Cannot eat & Liquids \\
\hline
\end{tabular}

The dysphagia score is the sum of the scores on the two scales and was recorded as a total score out of 12 . * Frequency of dysphagia; ${ }^{\dagger}$ Dysphagia associated with food type

either remained asymptomatic while on one of the two medications or developed recurrent symptoms of dysphagia requiring redilation within one year of their last bougienage. Dilations that were complicated by perforation were treated either surgically or conservatively.

Probabilities: The estimated probabilities of a patient requiring redilation while on omeprazole or ranitidine over a one-

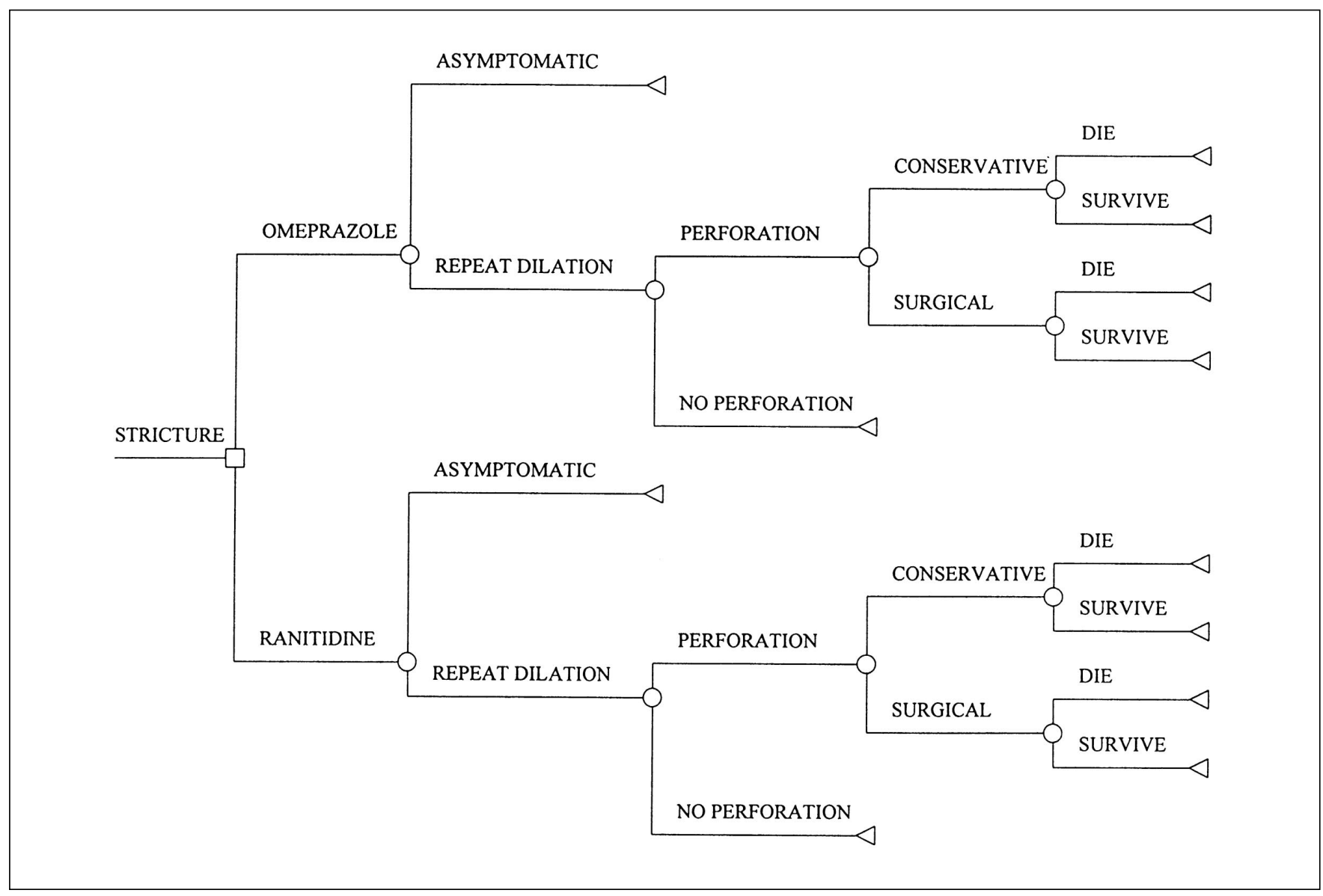

Figure 1) Decision tree for maintenance therapy of patients with peptic structure who required esophageal dilation. The decision tree identifies decision alternatives and their clinical outcomes. The possible outcomes are represented by chance nodes (O). $\square$ Decision node; $\Delta$ Terminal node 
TABLE 2

Summary of the estimated costs used in the decision analysis

\begin{tabular}{lc}
\hline Treatment & Cost (\$) \\
\hline Omeprazole 20 mg daily (one-year supply) & 931 \\
Ranitidine 150 mg bid (one-year supply) & 358 \\
Esophageal dilation & 101 \\
$\begin{array}{l}\text { Surgical treatment of esophageal perforation, and } \\
14 \text { day in-patient hospital stay }\end{array}$ & 7,576 \\
$\begin{array}{l}\text { Conservative (nonoperative) treatment of } \\
\text { esophageal perforation, and 14-day in-patient } \\
\text { hospital stay }\end{array}$ & 4,166 \\
\hline
\end{tabular}

year period were $30 \%$ and $46 \%$, respectively (7). The estimated risk of esophageal perforation during dilation of a peptic stricture was $0.09 \%$ (13-15). In the event of perforation, the probability of requiring surgical intervention was estimated to be $68 \%$, while the remainder were treated conservatively (16-22). The estimated mortality rate following surgical or conservative treatment of esophageal perforation was $13 \%(16-22)$.

Costs: Costs of a one-year supply of omeprazole and ranitidine, esophageal dilation, and surgical and conservative treatment of esophageal perforation were estimated from the perspective of a third-party payer. Estimated costs of esophageal dilation and treatment of perforation included both professional and hospital fees. The costs of both the surgical and nonoperative treatment of perforation were based on a 14-day hospital stay and included the costs of laboratory tests, intravenous solutions, parenteral nutrition and antibiotics. A summary of these costs is provided in Table 2. All costs were obtained from Canadian hospital data.

Utilities: Utility scores were obtained by using both the standard gamble (SG) and time trade-off (TTO) methods of utility calculation (9). The TTO method requires subjects to quantify the life expectancy that they would sacrifice to avoid a specified health state or intervention. The SG method requires that a subject choose between remaining in a specified chronic health state and undergoing an intervention that is associated with a given risk of mortality. The utility score is obtained by varying the risk of mortality associated with the intervention until the subject is indifferent to the two alternatives. The SG approach is best suited for utility measurement of potentially chronic health states such as dysphagia. However, because it lends itself poorly to measuring the disutility associated with discrete events or interventions, such as esophageal dilation or esophageal perforation requiring surgery, the TTO was also used.

Utility scores were obtained for dysphagia both before and after dilation based on patients' recall of symptoms surrounding the time of their last dilation. The difference in SG values was multiplied by the duration of dysphagia (before the most recent redilation) to arrive at a disutility score for dysphagia measured in QALYs. From this score, an average disutility score for dysphagia was calculated, and this value
TABLE 3

Summary of patients' symptoms and utilities for dysphagia

\begin{tabular}{lccc}
\hline & $\begin{array}{c}\text { Before dilation } \\
\text { (mean } \pm \text { SE) }\end{array}$ & $\begin{array}{c}\text { After dilation } \\
\text { (mean } \pm \text { SE) }\end{array}$ & P \\
\hline $\begin{array}{c}\text { Mean dysphagia } \\
\text { score }\end{array}$ & $6.4 \pm 0.9$ & $0.7 \pm 0.7$ & 0.00004 \\
$\begin{array}{c}\text { Mean utility score } \\
\text { (TTO method) }\end{array}$ & $0.950 \pm 0.019$ & $0.998 \pm 0.002$ & 0.02 \\
$\begin{array}{c}\text { Mean utility score } \\
\text { (SG method) }\end{array}$ & $0.900 \pm 0.041$ & $0.994 \pm 0.004$ & 0.03 \\
\hline $\begin{array}{l}\text { Dysphagia score reflects the sum of results from the frequency and diet scales } \\
\text { described in Table 1. SG Standard gamble; TTO Time trade-off }\end{array}$ &
\end{tabular}

was incorporated into the decision tree model. An average disutility score for esophageal dilation was generated using the TTO technique. This value was added to the disutility score for dysphagia. Disutility scores for esophageal perforation, and surgical and nonoperative treatment were obtained from 20 health professionals by using the TTO approach. The average of these scores was included in the decision model. Disutility of death from esophageal perforation was obtained by using the mean age of the patients in Smith and co-workers' (7) peptic stricture study, 71 years, and calculating life expectancy from Canada life tables (23).

Sensitivity analysis: A one-way sensitivity analysis was performed on all of the input variables across their clinically plausible ranges to determine the impact of each variable on the overall cost:utility ratio.

Statistics: For statistical analysis, Student's $t$ test for paired data was used. Differences were considered significant at $\mathrm{P}<0.05$. Data were averaged and expressed as the mean $\pm \mathrm{SE}$.

\section{RESULTS}

Utility scores: The average age of the patients who underwent a utility assessment was $64.4 \pm 4.3$ years (range four to 82 ) with an equal male:female ratio. Of the 10 patients studied, seven were receiving a PPI, two were using an $\mathrm{H}_{2} \mathrm{RA}$ and one was not taking any medication. The mean cumulative number of dilations that these patients underwent was $7.7 \pm 1.5$ (range two to 14). The mean time between their last dilation and the utility assessment was $56.5 \pm 20.5$ days (range one to 201). Four of 10 patients complained of heartburn. Dysphagia and utility scores of these patients are summarized in Table 3. All 10 patients experienced symptomatic improvement following dilation, reflected by a decrease in their dysphagia scores and an increase in their utility values. Although the improvement in the dysphagia scores following dilation was relatively large compared with the increase in the utility scores for dysphagia, all differences were statistically significant. Only one patient complained of any residual dysphagia following dilation.

The incremental cost of omeprazole compared with ranitidine in this decision analysis was $\$ 556$ per patient treated. The incremental utility gain of omeprazole was 0.0112 QALYs (the equivalent of four days). Overall, the incre- 
mental cost:utility ratio of omeprazole in the maintenance therapy of patients with peptic esophageal stricture was $\$ 49,600$ per QALY gained.

Sensitivity analysis: A sensitivity analysis was done to evaluate the effects of the variation of all of the independent costs, probabilities and utility assumptions used in the decision model. The baseline estimates and results of the sensitivity analysis are summarized in Table 4. Disutility associated with dysphagia and dilation had the greatest impact on the overall cost:utility ratio, reflected by the huge variation in the cost:utility ratio of $\$ 1.85$ million to $\$ 11,800$ per QALY. The highest individual disutility score for dysphagia and dilation among the 10 patients ( 0.32 QALYs) was used as the upper limit of the range in variation. The other estimated disutility scores had a small impact on the cost:utility ratio.

Among the estimated probabilities used in the decision model, varying the risk of requiring redilation while taking either omeprazole or ranitidine brought about the most significant change in the cost:utility ratio. Adjusting the risk of perforation from dilation over a wide range of probabilities resulted in an intermediate change in the cost:utility ratio. The upper limit of the range in the probability of perforation was obtained from a study that evaluated patients undergoing dilation for peptic stricture in which the perforation rate (0.013) was much higher than that reported by most studies (4). Adjusting either the estimated probability of requiring surgery for perforation or the associated mortality rate had little effect on the cost:utility ratio.

Varying the cost of either omeprazole or ranitidine had a large impact on the cost:utility ratio. The upper limit of the range in variation surrounding the estimated cost of omeprazole reflects the cost of doubling the dose. Regarding the sensitivity analysis of the cost of ranitidine, the range limits of $\$ 180$ and $\$ 709$ reflect the costs of other equivalent $\mathrm{H}_{2} \mathrm{RAs}$ available in the Canadian market. Variations in the other estimated costs resulted in a small change in the range of costutilities.

Threshold analysis: A summary of the threshold cost and probability values necessary to equalize the total costs of omeprazole and ranitidine is provided in Table 5. Threshold analysis revealed that the cost of omeprazole would have to be decreased by at least 60\% (to less than $\$ 375$ ) to equalize the costs of the two medications. The probability of perforation resulting from dilation would have to be greater than $51 \%$ to render the costs of the medications equal. The analysis was unable to generate threshold values for the probability of either requiring redilation (regardless of medication) or requiring surgery from perforation because there was no possible variation in probability that would equalize the total costs of omeprazole and ranitidine.

\section{DISCUSSION}

Both chronic dysphagia and the need for esophageal redilation contribute to the high morbidity of recurrent peptic stricture. Strictures are thought to recur as a result of ongoing gastroesophageal reflux, independent of coexisting heartburn or erosive esophagitis (2). PPIs, such as omeprazole, are the most potent acid-suppressive pharmacological agents currently available for controlling gastroesophageal reflux (24). Recent studies have demonstrated that omeprazole is

\section{TABLE 4}

Sensitivity analysis of cost, probability and utility estimates

\begin{tabular}{|c|c|c|c|}
\hline Variable & Baseline estimate & Range & $\begin{array}{l}\text { Range of cost-utility } \\
\text { (cost [\$] per QALY) }\end{array}$ \\
\hline \multicolumn{4}{|l|}{ Costs $(\$)$} \\
\hline Omeprazole 20 mg once daily for one year & 931 & $500-1,862$ & $11,200-132,000$ \\
\hline Ranitidine 150 mg bid for one year & 358 & $180-709$ & $65,500-18,300$ \\
\hline Esophageal dilation & 101 & $50-300$ & $50,400-\$ 46,800$ \\
\hline Surgical treatment of perforation & 7,576 & $5,000-20,000$ & $49,700-\$ 49,500$ \\
\hline Conservative treatment of perforation & 4,166 & $2,000-20,000$ & $49,600-49,600$ \\
\hline \multicolumn{4}{|l|}{ Probabilities } \\
\hline Requiring redilation while on omeprazole & 0.30 & $0.20-0.40$ & $30,100-135,200$ \\
\hline Requiring redilation while on ranitidine & 0.46 & $0.40-0.60$ & $80,700-25,800$ \\
\hline Perforation resulting from dilation & 0.0009 & $0.000-0.013$ & $51,200-36,200$ \\
\hline Requiring surgery if perforation occurs & 0.68 & $0.25-1.00$ & $49,900-49,700$ \\
\hline Mortality rate with surgical therapy & 0.13 & $0.05-0.50$ & $50,200-48,000$ \\
\hline Mortality rate with conservative therapy & 0.13 & $0.05-0.50$ & $50,000-48,900$ \\
\hline \multicolumn{4}{|l|}{ Utilities (QALY) } \\
\hline Dysphagia and dilation & 0.068 & $0.00-0.32$ & $1,850,000-11,800$ \\
\hline Perforation treated surgically & 0.508 & $0.00-2.00$ & $50,100-49,200$ \\
\hline Perforation treated conservatively & 0.242 & $0.00-2.00$ & $49,900-49,500$ \\
\hline Death & 12.50 & $2.00-40.0$ & $50,700-47,600$ \\
\hline
\end{tabular}

QALY Quality-adjusted life-year 
TABLE 5

Threshold values necessary to equalize the costs of omeprazole and ranitidine

\begin{tabular}{|c|c|c|}
\hline & $\begin{array}{l}\text { Baseline } \\
\text { estimate }\end{array}$ & Threshold \\
\hline \multicolumn{3}{|l|}{ Costs $(\$)$} \\
\hline $\begin{array}{l}\text { Omeprazole } 20 \mathrm{mg} \\
\text { once daily for one year }\end{array}$ & 931 & Less than 375 \\
\hline $\begin{array}{l}\text { Ranitidine } 150 \text { mg bid } \\
\text { for one year }\end{array}$ & 358 & More than 914 \\
\hline Esophageal dilation & 101 & More than 3,575 \\
\hline $\begin{array}{l}\text { Surgical treatment of } \\
\text { perforation }\end{array}$ & 7,576 & $\begin{array}{l}\text { More than } \\
5.7 \text { million }\end{array}$ \\
\hline $\begin{array}{l}\text { Conservative treatment } \\
\text { of perforation }\end{array}$ & 4,166 & $\begin{array}{l}\text { More than } \\
12.1 \text { million }\end{array}$ \\
\hline \multicolumn{3}{|l|}{ Probabilities } \\
\hline $\begin{array}{l}\text { Requiring redilation } \\
\text { (omeprazole) }\end{array}$ & 0.30 & Not possible \\
\hline $\begin{array}{l}\text { Requiring redilation } \\
\text { (ranitidine) }\end{array}$ & 0.46 & Not possible \\
\hline Perforation from dilation & 0.0009 & More than 0.51 \\
\hline $\begin{array}{l}\text { Requiring surgery for } \\
\text { perforation }\end{array}$ & 0.68 & Not possible \\
\hline
\end{tabular}

superior to ranitidine as maintenance therapy in the prevention of recurrent strictures $(7,8)$. The high daily cost of omeprazole must be weighed against the end result of fewer dilations (and decreased costs associated with less frequent dilations) and the associated increased utility.

This decision model revealed that the incremental cost:utility ratio of omeprazole in the maintenance therapy of patients with peptic esophageal stricture was $\$ 49,600$ per QALY gained. Although omeprazole clearly provides this patient population with increased utility compared with ranitidine, this improvement in utility is not without substantial financial cost. Whether the cost:utility ratio of omeprazole is clinically and economically attractive enough to recommend widespread use in this clinical setting is unclear.

A recent review by Laupacis et al (25) provided tentative guidelines for using clinical and economic evaluations of medical strategies. Technologies or therapies that were both more effective and more expensive were placed into one of three categories. Therapies that cost less than $\$ 20,000$ per QALY gained are almost universally accepted. In contrast, the authors do not recommend therapies that cost more than $\$ 100,000$ per QALY gained. The cost:utility ratio of omeprazole in our study was $\$ 49,600$ per QALY gained. Laupacis et al (25) suggested that there is moderate evidence to support the use of treatments costing between $\$ 20,000$ and $\$ 100,000$ per QALY gained. They cite many treatments in this costutility range that are provided regularly, such as hospital hemodialysis ( $\$ 65,500$ per QALY) and the use of nonionic contrast media to high risk patients ( $\$ 23,000$ per QALY).

Given that previous studies have not found $\mathrm{H}_{2} \mathrm{RAs}$ to be useful in preventing the recurrence of peptic stricture, it is logical to determine the cost:utility ratio comparing the use of omeprazole with no pharmacological maintenance therapy. This assumes that the frequency of redilation without acid-suppressive therapy is no more than that with ranitidine. In this scenario, the incremental cost:utility ratio of omeprazole is $\$ 81,600$ per QALY gained. Although this value is considerably greater than the cost:utility ratio of omeprazole compared with ranitidine, omeprazole may still be considered a reasonable strategy given the economic guidelines described above.

Sensitivity analysis revealed that among the cost, probability and utility assumptions used in the decision analysis, the estimates that had the greatest impact on the overall cost:utility ratio were disutility associated with dysphagia and dilation, probability of requiring redilation, and cost of the medications. Disutility scores for dysphagia and dilation were accurately obtained in this study from the mean scores of 10 patients by using accepted methods of utility calculation. The costs of the medications used in the analysis reflect current market prices in Canada. The estimated probabilities of requiring redilation while on omeprazole or ranitidine are likely to be accurate because they were based on the published results of a large, well designed study that specifically compared the two medications in the prevention of stricture recurrence (7). Although the decision analysis was limited to one year, a recent study by Agnew et al (26) demonstrated that the frequency of dilations in the first year of treatment is predictive of the frequency in subsequent years. Variations in the other utility, probability and cost estimates resulted in only minor changes in the cost:utility ratio because the risk of perforation associated with dilation was so low. Similarly, the unrealistically high threshold costs associated with dilation and either surgical or conservative treatment of perforation reflect the lack of impact that these variables had on the cost:utility ratio.

\section{CONCLUSIONS}

Omeprazole $20 \mathrm{mg}$ once daily is associated with greater utility than ranitidine $150 \mathrm{mg}$ bid when used as prophylaxis against peptic esophageal stricture recurrence. This increased utility is at the expense of substantial financial cost. Nevertheless, omeprazole may be considered clinically and economically attractive enough to warrant widespread use in this setting. The cost:utility ratio in this model is significantly influenced not only by the cost of the medication, but also by the patients' perception of their state of health, as reflected by the disutility scores for dysphagia and esophageal dilation.

\section{REFERENCES}

1. Rejeb BM, Bouche O, Zeitoun P. Study of 47 consecutive patients with peptic esophageal stricture compared with 3880 cases of reflux esophagitis. Dig Dis Sci 1992;37:733-6.

2. Glick ME. Clinical course of esophageal stricture managed by bougienage. Dig Dis Sci 1982;27:884-8.

3. Patterson DJ, Graham DY, Smith JL, et al. Natural history of benign esophageal stricture treated by dilatation. Gastroenterology $1983 ; 85: 346-50$. 
4. Hands LJ, Papavramidis S, Bishop H, et al. The natural history of peptic oesophageal strictures treated by dilatation and antireflux therapy alone. Ann R Coll Surg Engl 1989;71:306-9.

5. Ferguson R, Dronfield MW, Atkinson M. Cimetidine in treatment of reflux esophagitis with peptic stricture. BMJ 1979;2:472-4.

6. Farup PG, Modalsli B, Tholfsen JK. Long-term treatment with $300 \mathrm{mg}$ ranitidine once daily after dilatation of peptic oesophageal strictures. Scand J Gastroenterol 1992;27:594-8.

7. Smith PM, Kerr GD, Cockel R, et al. A comparison of omeprazole and ranitidine in the prevention of recurrence of benign esophageal stricture. Gastroenterology 1994;107:1312-8.

8. Marks RD, Richter JE, Rizzo J, et al. Omeprazole versus $\mathrm{H}_{2}$-receptor antagonists in treating patients with peptic stricture and esophagitis. Gastroenterology 1994;106:907-15.

9. Drummond MF, Soddart GL, Torrance GW. Cost-utility analysis. In: Drummond MF, Soddart GL, Torrance GW, eds. Methods for the Economic Evaluation of Health Care Programs. Oxford: Oxford University Press, 1987:112-48.

10. Cox JGC, Winter RK, Maslin SC, et al. Balloon or bougie for dilatation of benign oesophageal stricture? An interim report of a randomized controlled trial. Gut 1988;29:1741-7.

11. McClave SA, Wright RA, Brady PG. Prospective randomized study of Maloney esophageal dilatation - blinded versus fluoroscopic guidance. Gastrointest Endosc 1990;36:272-5.

12. Pauker SG, Kassirer JP. Decision analysis. N Engl J Med 1987;316:250-8

13. Silvis SE, Nebel O, Rogers G, et al. Endoscopic complications: Results of the 1974 American Society for Gastrointestinal Endoscopy survey. JAMA 1976;235:928-30.

14. Mandelstam P, Sugawa C, Silvis SE, et al. Complications associated with esophagogastroduodenoscopy and with esophageal dilation. Gastrointest Endosc 1976;23:16-9.
15. Cox JGC, Bennett JR. Benign esophageal strictures. In: Bennet JR, Hunt RH, eds. Therapeutic Endoscopy and Radiology of the Gut, 2nd edn. Baltimore: Williams \& Wilkins, 1990:11.

16. Wesdorp ICE, Bartelsman JFWM, Den Hartog Jagar FCA, et al. Results of conservative treatment of benign esophageal strictures: a follow-up study in 100 patients. Gastroenterology 1982;82:487-93.

17. Goldstein LA, Thompson WR. Esophageal perforations: a 15 year experience. Am J Surg 1982;143:495-503.

18. Sarr MG, Pemberton JH, Spencer Payne W. Management of instrumental perforations of the esophagus. J Thorac Cardiovasc Surg 1982;84:211-8.

19. Larsen K, Jensen BS, Axelsen F. Perforation and rupture of the esophagus. Scand J Thorac Cardiovasc Surg 1983;17:311-6.

20. Ajalat GM, Mulder DG. Esophageal perforations: the need for an individualized approach. Arch Surg 1984;119:1318-20.

21. Wesdorp ICE, Bartelsman JFWM, Huibregtse K, et al. Treatment of instrumental oesophageal perforation. Gut 1984;25:398-404.

22. Radmark T, Sandberg N, Petersson G. Instrumental perforation of the oesophagus: a ten year study from two ENT clinics. J Laryngol Otol 1986;100:461-5.

23. Statistics Canada. Life Tables, Canada and Provinces, 1990. 1992. Ottawa: Statistics Canada, Health Statistics Division, 1995:1-5.

24. Pope CE. Acid-reflux disorders. N Engl J Med 1994;331:656-60.

25. Laupacis A, Feeny D, Detsky AS, et al. How attractive does a new technology have to be to warrant adoption and utilization? Tentative guidelines for using clinical and economic evaluations. Can Med Assoc J 1992;146:473-81

26. Agnew SR, Pandya SP, Reynolds RPE, et al. Predictors of frequent esophageal dilations of benign peptic strictures. Dig Dis Sci 1996;41:931-6. 


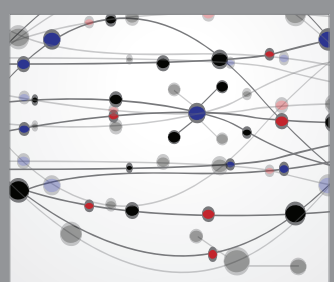

The Scientific World Journal
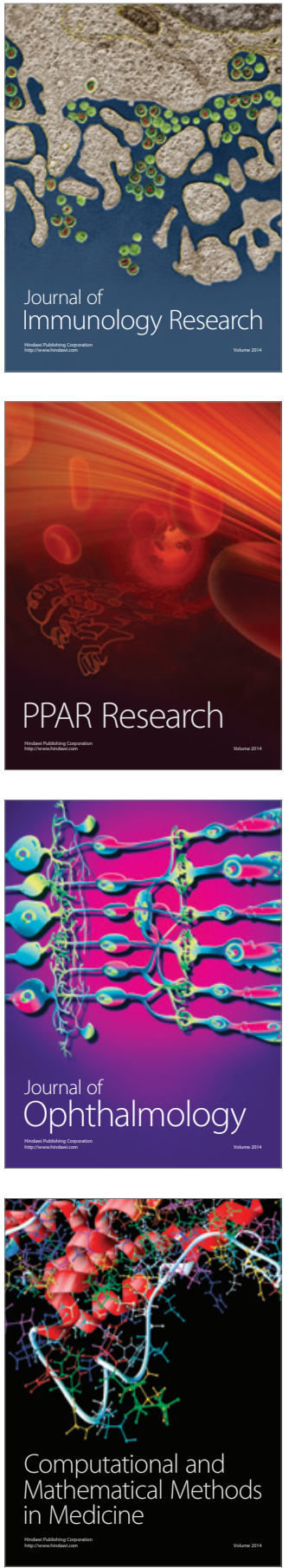

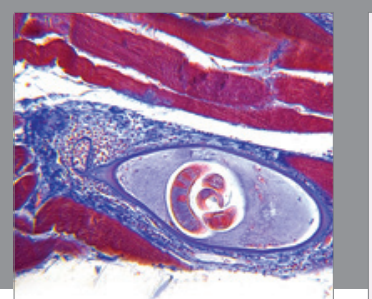

Gastroenterology Research and Practice

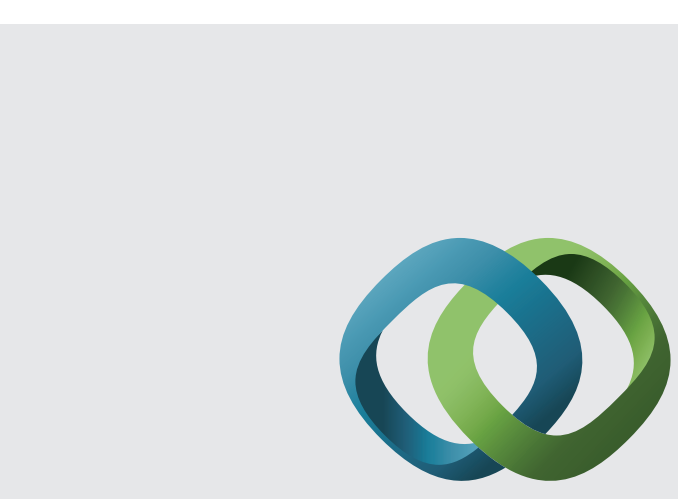

\section{Hindawi}

Submit your manuscripts at

http://www.hindawi.com
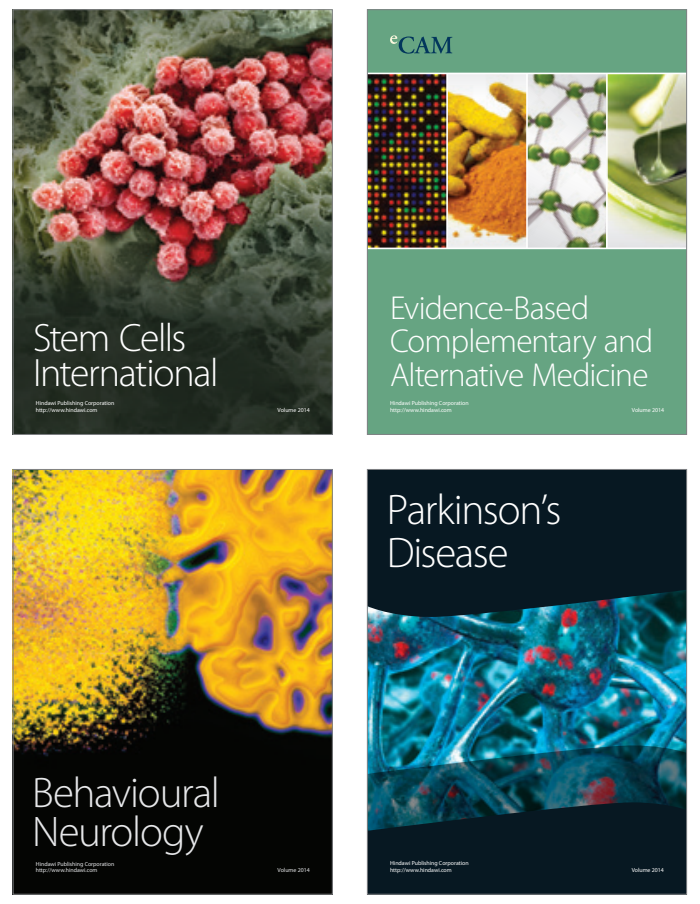
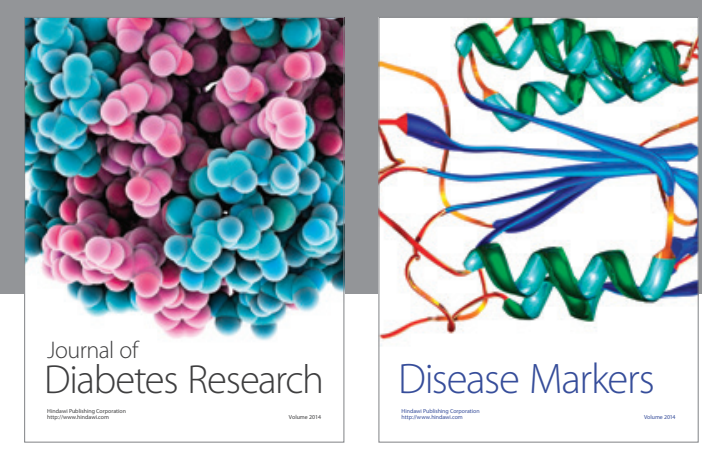

Disease Markers
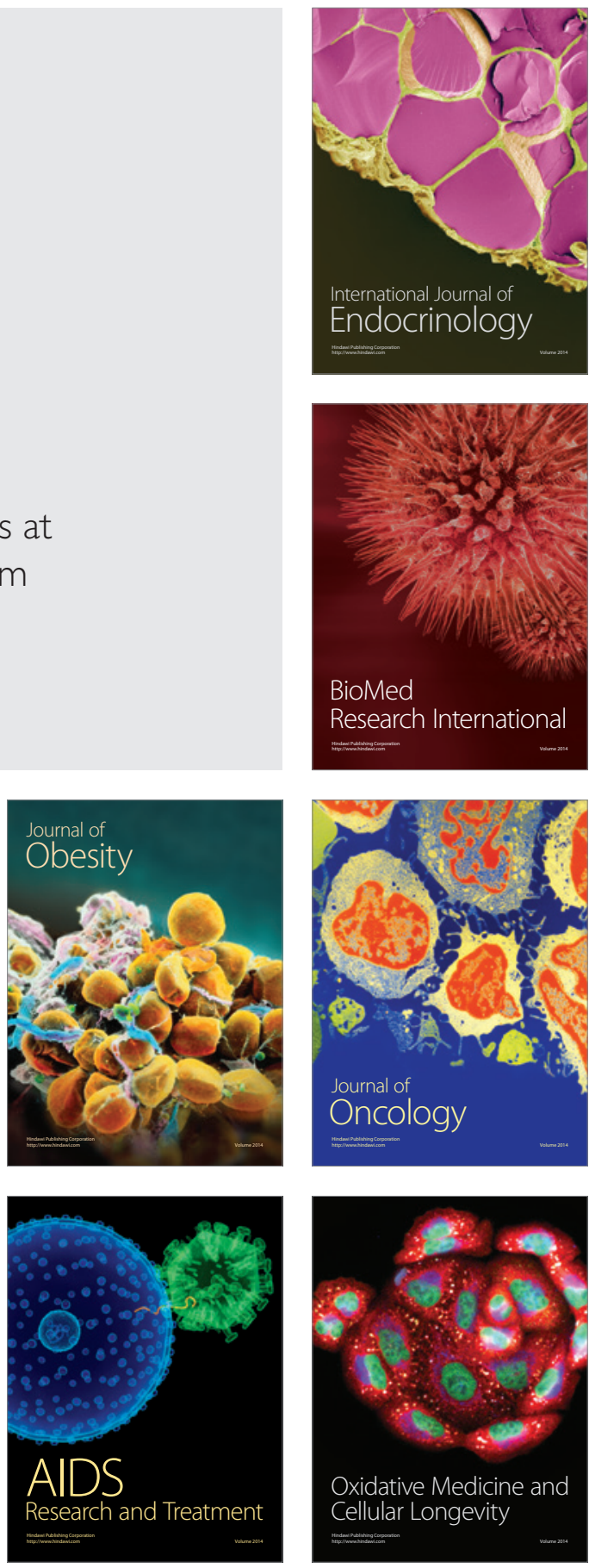